\title{
$\mathrm{TiO}_{2}$ によるセレン酸イオンの光触媒還元反応に 及ぼす有機酸の影響
}

\author{
佐貫須美子 1 䒴 村 理 香 $1, * 1$ \\ 1富山大学工学部物質生命システム工学科 \\ 2京都大学名誉教授, チタン工業株式会社特別顧問 \\ J. Japan Inst. Metals, Vol. 67, No. 1 (2003), pp. 61-65 \\ (C) 2003 The Japan Institute of Metals
}

喜 多宣 明 $1, * 2$

真嶋宏 2

\section{Effect of Organic Acid Reductants on Photocatalytic Reduction of Selenate Solutions Using a $\mathrm{TiO}_{2}$ Catalyst}

\author{
Sumiko Sanuki1 ${ }^{1}$, Rika Yoshimura, ${ }^{1 * 1}$, Nobuaki Kita ${ }^{1, * 2}$ and Hiroshi Majima ${ }^{2}$ \\ ${ }^{1}$ Department of Material Systems Engineering and Life Science, Faculty of Engineering, Toyama University, Toyama 930-8555 \\ ${ }^{2}$ Emeritus Professor, Kyoto University, and Special Advisor, Titan Kogyo K.K., Ube 755-8567
}

The effect of organic acid reductants including formic acid, citric acid, oxalic acid, and tartaric acid, on the photocatalytic reduction of aqueous $\mathrm{Se}(\mathrm{VI})$ solutions was studied using $\mathrm{TiO}_{2}$ catalyst. Among the organic acids examined, formic acid was found most effective in accelerating photocatalytic reduction of Se(VI). Although tartaric acid seemed to be another important acid, it failed to complete the reduction of Se(VI). Although these organic acids were photocatalytically oxidized, their oxidation rates and amounts were small. To reduce $\mathrm{Se}(\mathrm{VI})$ to $\mathrm{H}_{2} \mathrm{Se}, 4 \sim 5$ molar equivalent organic acid was oxidized. However, simple chemical reduction of Se (VI) by organic acid did not occur. It is thought that the photocatalytic reduction of Se(VI) by efficient use of electrons formed on $\mathrm{TiO}_{2}$ catalyst was accelerated by the consumption of positive holes by organic acid.

(Received September 11, 2002; Accepted November 29, 2002)

Keywords: photocatalytic reduction, $\mathrm{Se}(\mathrm{VI}), \mathrm{TiO}_{2}$ powder, organic acid reductants

\section{1.は じめに}

近年光触媒の基礎・応用両面での研究が活発に行われるよ うになり，応用面では現在約 20 品目以上の商品に利用され ているとのことであり ${ }^{11}$, 防污など効果的に利用されている 分野もあるが，全般としては経済的な効果面で考えると未だ これからの開発が待たれる分野と言った感が強い.

著者らは環境問題への応用例として, 硫化鉱の焙焼炉ガス 中に含まれ, 硫化鉱の製鍊工程や $\mathrm{SO}_{2}$ ガスからの硫酸製造 に際してその処理と回収が問題となるセレンの除去に光触媒 還元反応を応用する立場から, 廃水中に含まれるセレン酸イ オン (酸性条件下では $\mathrm{SeO}_{4}^{2-}$ イオン, 以下 $\mathrm{Se}(\mathrm{VI})$ と記載)を 対象として研究し，その結果の一部は既に報告した ${ }^{2,3)}$. Se (VI)の光触媒還元に関しては著者らと若干異なった立場か ら行われている菊池らの報告もある4,5).

溶液中の $\mathrm{Se}(\mathrm{VI})$ は安定で, ギ酸のような還元性の酸を添 加しても $\mathrm{Se}(\mathrm{VI})$ の還元反応は進行しないが， $\mathrm{TiO}_{2}$ のような 光触媒存在下で紫外線照射を行うと容易に還元される. 本研 究はギ酸以外にもクエン酸, シュウ酸ならびに酒石酸といっ

*1 富山大学学生(Undergraduate Student, Toyama University)

*2 富山大学大学院生 (Graduate Student, Toyama University)
た有機酸が $\mathrm{Se}(\mathrm{VI})$ の光還元反応において，どのように作用 するかを明らかにする目的で行ったものである。

\section{2. 実 験 方 法}

\section{1 光触媒}

本研究に使用した光触媒は, 比表面積 $47.6 \mathrm{~m}^{2} / \mathrm{g}, 70 \%$ ア ナターゼ型の $\mathrm{TiO}_{2}$ (日本アエロジル製 $\left.\mathrm{P}-25\right)$ を使用した.

\section{2 供試液の調製}

試薬の $\mathrm{Na}_{2} \mathrm{SeO}_{4}$ を比抵抗 $5.0 \times 10^{4} \Omega \cdot \mathrm{m}$ 以上の脱イオン水 に Se $(\mathrm{VI})$ 濃度が $100 \mathrm{ppm}$ の濃度になるように溶解し, 正孔 による還元生成物の再酸化を防ぐため, 還元剤として $2.5 \times$ $10^{-2} \mathrm{kmol} / \mathrm{m}^{3}$ のギ酸, クエン酸, シュウ酸または酒石酸を 添加した。 また供試溶液は $\mathrm{NaOH}$ を溶解して調製した水溶 液を用いて pH 3.0 に調製して実験に供した。用いた試薬は いずれも試薬特級として市販のものである.

\section{3 実験方法}

実験装置は，前報3)に示したように Se (VI)を含む水溶液 の蒸発を防ぐための純水槽, 光触媒反応槽抢よび排力゙スの卜 ラップ槽からなる. 紫外光の光源として東芝製 BLB 蛍光灯 $20 \mathrm{~W}$ を 10 本用い, 側面から反応容器に照射した. 使用し 
た $\mathrm{BLB}$ 蛍光灯の最強波長は $352 \mathrm{~nm}$ であり, $\mathrm{TiO}_{2}$ 半導体触 媒を励起させるのに十分なものである。 また，実験装置は， $50 \mathrm{~cm} \times 60 \mathrm{~cm} \times 80 \mathrm{~cm}$ の $\mathrm{Al}$ 板製箱中に設置し, 反応容器に 照射される紫外線強度は, 照射する BLB 蛍光灯の数を調節 することで 46 または $70 \mathrm{~W} / \mathrm{m}^{2}$ 一定とした.

反応容器のムエンケ式ガス洗浄瓶に $\mathrm{Se}(\mathrm{VI})$ を含む水溶液 $1 \times 10^{-4} \mathrm{~m}^{3}$ を取り， $\mathrm{TiO}_{2}$ 粉末を加え，マグネチックスター ラーで懸濁させた。 $\mathrm{N}_{2}$ ガスを通気し，その排気ガスは，3.0 $\times 10^{-3} \mathrm{kmol} / \mathrm{m}^{3}$ 硫酸銅水溶液および $0.1 \mathrm{kmol} / \mathrm{m}^{3}$ 水酸化小 トリウム水溶液に通して排気した。 あらかじめ $\mathrm{N}_{2}$ ガスを $1.8 \mathrm{ks}$ 通気し予備脱気の後, 光照射を始め反応を開始した. 一定時間照射を行い，消灯後発生した排ガスを完全に硫酸銅 水溶液中にトラップするため,さらに継続して $1.8 \mathrm{ks} \mathrm{N}$ ガ スの通気を行った。

その後, 反応液中の $\mathrm{TiO}_{2}$ 粉末と沈殿物を遠心分離により 分離し, 溶液中の残存セレンイオン濃度, 沈殿物中の単体セ レン $\left(\mathrm{Se}^{0}\right)$ 量を測定した。 また，排ガスをトラップした硫酸 銅水溶液中の残存 $\mathrm{Cu}^{2+}$ イオン濃度の測定によりセレン化水 素 $\left(\mathrm{H}_{2} \mathrm{Se}\right)$ 濃度を求めた。

\section{$2.4 \mathrm{TiO}_{2}$ 触媒上への $\mathrm{Se}(\mathrm{VI})$ の吸着量の測定}

吸着実験に使用した溶液は，Se(VI)濃度が 100 ppm にな るように, $\mathrm{Na}_{2} \mathrm{SeO}_{4}$ を溶解し， $2.5 \times 10^{-2} \mathrm{kmol} / \mathrm{m}^{3}$ のギ酸， クエン酸, シュウ酸または酒石酸を添加し, $\mathrm{NaOH}$ 水溶液 で $\mathrm{pH}$ を 3.0 に調製した。この溶液を遠心沈殿管に入れ， $\mathrm{TiO}_{2}$ 触媒を $11 \mathrm{~kg} / \mathrm{m}^{3}$ になるように加え, $298 \pm 1 \mathrm{~K}$ の恒温 槽で $1.8 \mathrm{ks}$ 振とうし平衡化した。 その後, 遠心分離により $\mathrm{TiO}_{2}$ を分離し溶液中の $\mathrm{Se}(\mathrm{VI})$ 濃度を定量した. $\mathrm{TiO}_{2}$ 上の 吸着 $\mathrm{Se}(\mathrm{VI})$ 量は初濃度より差し引くことにより決定した。

\section{5 分析方法}

水溶液中の溶存 $\mathrm{Se}(\mathrm{VI})$ 濃度は, 水素化物発生装置を付加 した日本ジャーレル・アッシュ社製 AA-880 mark II 型原子 吸光光度計を用いて定量した。なお，この水素化物発生によ る原子吸光法は，亜セレン酸イオン $(\mathrm{Se}(\mathrm{IV}))$ の微量定量を 行うものであり, Se(VI)の定量は不可能である.そこで, 試料溶液に塩酸を加え煮沸することにより $\mathrm{Se}(\mathrm{VI})$ を $\mathrm{Se}$ (IV) イオンに還元する予備化学処理法を行ったのち分析し た $^{6)}$.

また $\mathrm{Se}^{0}$ と触媒 $\mathrm{TiO}_{2}$ はガラスフィルターを用い吸引濾過 した後水洗し, $\mathrm{Se}^{0}$ の定量に供した. 濾過物中の $\mathrm{Se}^{0}$ 濃度は, $\mathrm{HNO}_{3}$ 水溶液で $\mathrm{Se}^{0}$ を溶解し, $\mathrm{TiO}_{2}$ と分離し $\mathrm{Se}^{0}$ 濃度を定 量した.

排気ガスに含まれる $\mathrm{H}_{2} \mathrm{Se}$ ガスは，これを硫酸銅水溶液で 捕集することにより CuSe の沈殿物を生成するので，硫酸銅 水溶液中の $\mathrm{Cu}^{2+}$ イオン濃度の減少量から $\mathrm{H}_{2} \mathrm{Se}$ 量を算出し た。なお $\mathrm{Cu}^{2+}$ イオン濃度は, 原子吸光光度法で定量した。

水溶液中の有機酸の分析は，東ソ一製 CO-8020 型液体ク ロマトグラフィーを用い， $1 \% \mathrm{H}_{3} \mathrm{PO}_{4}$ を溶離液とした $\mathrm{TSK}_{\mathrm{gel}}$ SCX カラムおよび UV-8000 型 UV $(210 \mathrm{~nm})$ 検出器で分析 した.

\section{3. 実験結果および考察}

\section{1 有機酸存在下での $\operatorname{Se}(\mathrm{VI})$ の光触媒還元}

本研究の開始に先立ち, 光触媒として用いた濃度 $1.1 \mathrm{~kg} /$ $\mathrm{m}^{3}$ の $\mathrm{TiO}_{2}$ 粉末上への各種有機酸を含む $\mathrm{pH} 3.0, \mathrm{Se}(\mathrm{VI})$ 濃 度 $100 \mathrm{ppm}$ の液温 $298 \mathrm{~K}$ における $\mathrm{Se}(\mathrm{VI})$ の平衡吸着量を測 定したが，ギ酸の場合に $3.3 \mathrm{mg} / \mathrm{g}$ の $\mathrm{Se}(\mathrm{VI})$ が吸着された のみで, 他の有機酸の場合には Se(VI)の吸着は認められな かった

\subsection{1 ギ酸存在下での $\mathrm{Se}(\mathrm{VI})$ の光触媒還元}

Fig. 1(A) はギ酸存在下で濃度 $100 \mathrm{ppm}$ の Se(VI)を光触 媒還元した場合の速度曲線を示す。図から明らかなように $\mathrm{UV}$ 照射強度 $70 \mathrm{~W} / \mathrm{m}^{2}$ の場合 $\mathrm{Se}(\mathrm{VI})$ の減少率 $50 \%$ に達す るのに要する時間は $1.4 \mathrm{ks}$, 一方 $\mathrm{Se}^{0}$ 生成率 $75 \%$ のピーク に到達するのに要する時間は $2.7 \mathrm{ks}, \mathrm{H}_{2} \mathrm{Se}$ 生成が完了する までには $4.5 \mathrm{ks}$ が必要であった。この反応に拈いて中間生 成物として Se (IV) が検出されないことは，イオンクロマト グラフィーにより確認した。出発時の $\mathrm{Se}(\mathrm{VI})$ は $4.5 \mathrm{ks}$ では 完全に還元されている. $\mathrm{H}_{2} \mathrm{Se}$ の生成は $7.2 \mathrm{ks}$ 以降になって も完全ではないが, この点に関し, 初期 Se (VI)濃度からそ れぞれの反応時間における $\mathrm{Se}(\mathrm{VI}), \mathrm{Se}^{0}$ および $\mathrm{H}_{2} \mathrm{Se}$ 生成量 を差し引いた值をマで示した。この生成量は，反応槽とトラ ップ槽を接続するシリコンゴム管壁が赤褐色に変色すること から， $\mathrm{H}_{2} \mathrm{Se}$ ガスの捕集ロス量と考えられるが，明確ではな いため，本論文ではこの実験值を $\mathrm{H}_{2} \mathrm{Se}$ 生成量に含めずその

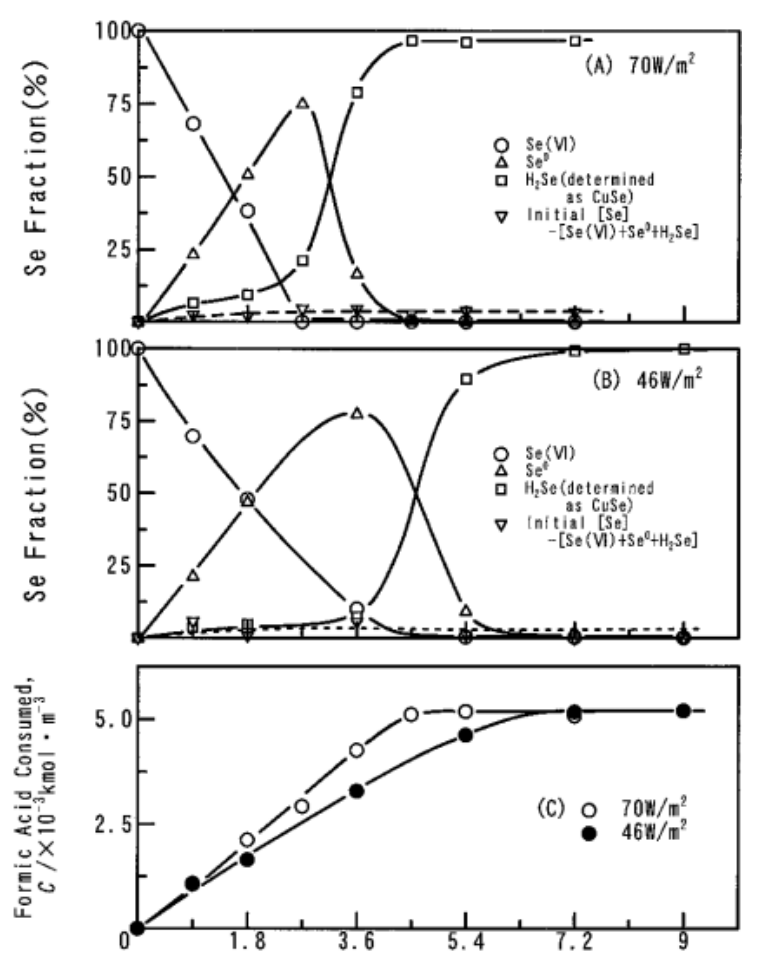

UV Irradiation Duration, $t / \mathrm{ks}$

Fig. 1 Rate curves for photocatalytic reduction of Se(VI) and formation of Se derivatives in the presence of formic acid and concentration change in formic acid determined at different intensities of UV radiation. 
まま図示した。

Fig. 1 (B) は UV 照射強度を $46 \mathrm{~W} / \mathrm{m}^{2}$ に変えた以外は Fig. 1(A) と同じ条件で行った還元反応の結果を示す. Se (VI) $50 \%$ 減少所要時間は $1.7 \mathrm{ks}$, 最大 $\mathrm{Se}^{0}$ 生成率は約 $75 \%$ であり, ピーク到達所要時間は $3.6 \mathrm{ks}$, また Se(VI)の還元 終了に要する時間は $7.2 \mathrm{ks}$ と, 照射強度 $70 \mathrm{~W} / \mathrm{m}^{2}$ の場合に 比して反応は遅く進行したが，UV 照射強度が小になったこ とを考えれば当然の帰結である.

一方 $\mathrm{Se}(\mathrm{VI})$ の光還元反応の進行に伴い系内に添加したギ 酸も分解する. Fig. 1(C)はその様相を示すが，UV 照射強 度 $70 \mathrm{~W} / \mathrm{m}^{2}$ の場合の方が $46 \mathrm{~W} / \mathrm{m}^{2}$ の場合に比べてやや勾 配が大になり濃度減少速度が大きい。さらに UV 照射強度 $70 \mathrm{~W} / \mathrm{m}^{2}$ の場合は反応時間 $4.5 \mathrm{ks}$ で， $46 \mathrm{~W} / \mathrm{m}^{2}$ の場合は $7.2 \mathrm{ks}$ でいずれも約 $5 \times 10^{-3} \mathrm{kmol} / \mathrm{m}^{3}$ の濃度低下を示し, それ以後ギ酸の分解は見られない。 またギ酸の分解が停止す る反応時間は $\mathrm{Se}(\mathrm{VI})$ の光還元反応の終了時間とほぼ一致し ている。

\subsection{2 クエン酸存在下での $\mathrm{Se}(\mathrm{VI})$ の光触媒還元}

Fig. 2 はギ酸の代わりにクエン酸を用いた以外は全て Fig. 1 と同条件で行った実験の結果を示す. Fig. 2(A) は 70 W/ $\mathrm{m}^{2}$ の場合であるが, 対応する Fig. 1(A) と比較すれば容易 に分かるように, Se (VI)の光触媒還元はギ酸の場合に比し て遅く, $\mathrm{Se}(\mathrm{VI})$ の $50 \%$ 減少に要する時間は $3.6 \mathrm{ks}, \mathrm{Se}^{0}$ 生成 率のピークは $25 \%$ と低く, ピーク位置到達時間は $5.4 \mathrm{ks}$, $\mathrm{H}_{2} \mathrm{Se}$ 生成反応終了には $9.0 \mathrm{ks}$ とギ酸を用いた場合の約 1.7 倍の時間が必要であり, ギ酸の場合に比して緩やかな反応で

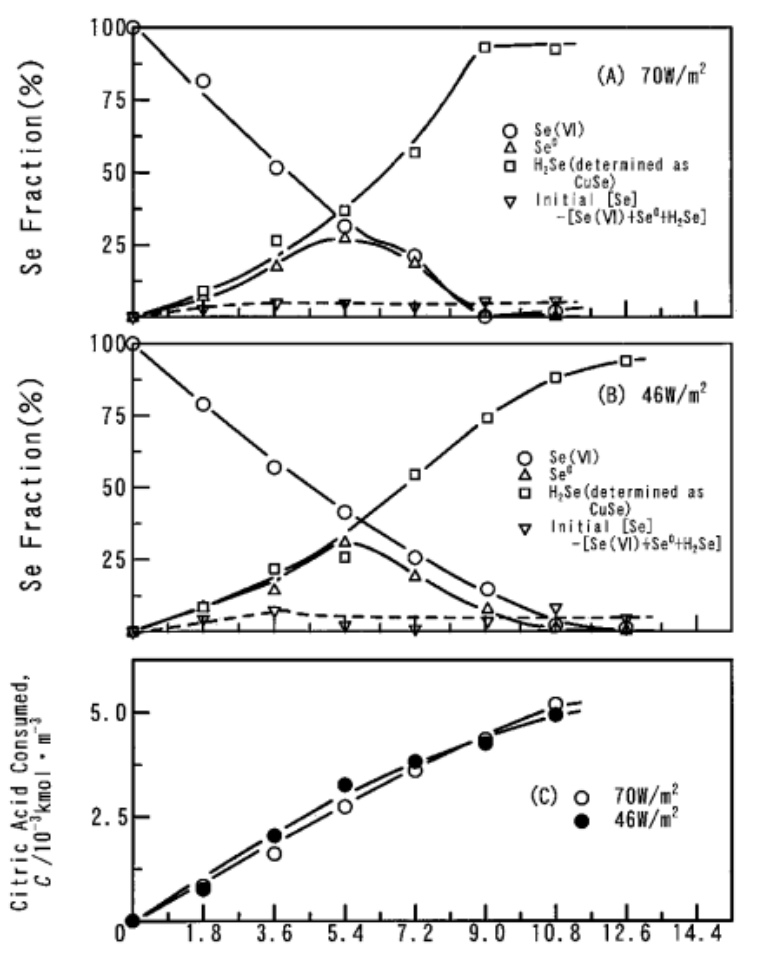

UV Irradiation Duration, $t / \mathrm{ks}$

Fig. 2 Rate curves for photocatalytic reduction of Se(VI) and formation of Se derivatives in the presence of citric acid and concentration change in citric acid determined at different intensities of UV radiation.
あった．Fig. 2(B)は UV 照射強度 $46 \mathrm{~W} / \mathrm{m}^{2}$ の場合の結果 であるが，クエン酸存在下でもギ酸と同様の傾向を示す。す なわち $\mathrm{Se}(\mathrm{VI}) 50 \%$ 減少率に達する時間は $4.6 \mathrm{ks}$ で，UV 照 射強度が減少しただけ反応は全般に遅くなる，最大 $\mathrm{Se}^{0}$ 生成 率は約 $30 \%$ と低く約 $5.4 \mathrm{ks}$ の時間を要し,さらに Se(VI)の 完全還元には $12.6 \mathrm{ks}$ 以上の時間を要した.

また Fig. $2(\mathrm{C})$ に示すようにクエン酸も $\mathrm{Se}(\mathrm{VI})$ の光触媒 還元反応の進行に伴い分解するが，クエン酸濃度の減少速度 はUV 照射強度の影響を殆ど受けない，照射時間 $10.8 \mathrm{ks}$ で 約 $5 \times 10^{-3} \mathrm{kmol} / \mathrm{m}^{3}$ の濃度低下である.

\subsection{3 シュウ酸存在下での $\mathrm{Se}(\mathrm{VI})$ の光触媒還元}

Fig. 3 は有機酸としてシュウ酸を用いた他は Fig. 1 のV 照射強度 $70 \mathrm{~W} / \mathrm{m}^{2}$ での実験条件と同じ条件下で行った実験 である. Se (VI)減少率 $50 \%$ 到達に要する時間は $4.5 \mathrm{ks}, \mathrm{Se}^{0}$ の最大生成率は約 $11 \%$ と極めて低くその時点到達に要する 時間は $5.4 \mathrm{ks}, \mathrm{Se}(\mathrm{VI})$ の完全消失時間は $10.8 \mathrm{ks}$ である.

Fig. 3(B)に示すようにシュウ酸も Se(VI)の還元反応に伴 い消費されるが，その量は $10.8 \mathrm{ks} に$ に抢いて約 $6 \times 10^{-3}$ $\mathrm{kmol} / \mathrm{m}^{3}$ であった。

\subsection{4 酒石酸存在下での $\mathrm{Se}(\mathrm{VI})$ の光触媒還元}

Fig. 4 は有機酸として酒石酸を用いた以外は Fig. 1 のV 照射強度 $70 \mathrm{~W} / \mathrm{m}^{2}$ と同条件での実験結果である. 図 $(\mathrm{A})$ に 示すように $\mathrm{Se}(\mathrm{VI}) 50 \%$ 減少に要する時間は $2.5 \mathrm{ks}, \mathrm{Se}^{0}$ 最大 生成率は約 $45 \%$ ，それに要する時間は $5.4 \mathrm{ks}$ であったが， $\mathrm{Se}(\mathrm{VI})$ の完全消失は $\mathrm{Se}^{0}$ 消滅所要時間である $10.8 \mathrm{ks}$ でも終 了しない点は他の有機酸の場合と異なる。

酒石酸も他の有機酸と同様 $\mathrm{Se}(\mathrm{VI})$ の光還元反応の進行に 伴い消費されるが UV 照射開始後 $10.8 \mathrm{ks}$ 時に消費された酒 石酸の量は $6.5 \times 10^{-3} \mathrm{kmol} / \mathrm{m}^{3}$ であった。

Fig. 1〜Fig. 4 の UV 照射強度 $70 \mathrm{~W} / \mathrm{m}^{2}$ の結果を比較す ると次のことが分かる。すなわち $\mathrm{Se}(\mathrm{VI}) 50 \%$ 減少率から判

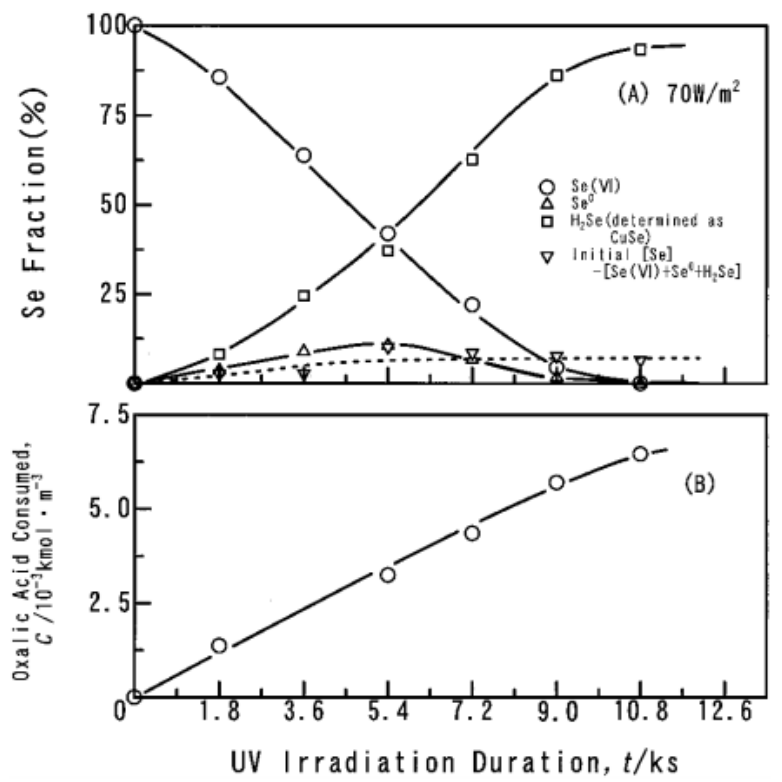

Fig. 3 Rate curves for photocatalytic reduction of Se(VI) and formation of Se derivatives in the presence of oxalic acid and concentration change in oxalic acid determined at $70 \mathrm{~W} / \mathrm{m}^{2}$ of UV light intensity. 


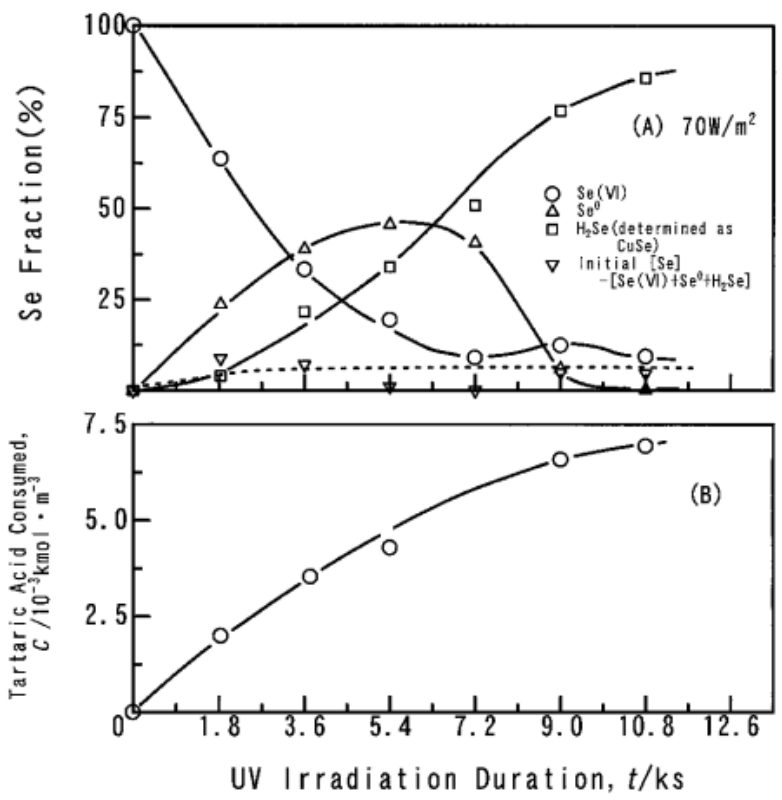

Fig. 4 Rate curves for photocatalytic reduction of Se(VI) and formation of Se derivatives in the presence of tartaric acid and concentration change in tartaric acid determined at $70 \mathrm{~W} / \mathrm{m}^{2}$ of UV light intensity.

断してギ酸を用いた場合が最も早く, 次いで酒石酸, クエン 酸およびシュウ酸の順になっている． $\mathrm{Se}^{0}$ 最大生成率も $\mathrm{Se}$ (VI) $50 \%$ 減少所要時間と同じ順序であり, ギ酸の $75 \%$ から シュウ酸の $11 \%$ と大幅に変化する. またその最大 $\mathrm{Se}^{0}$ 生成 率到達に要する時間はギ酸が特に早く $2.7 \mathrm{ks}$ であるのに対 し，他 3 者はいずれも約 $5.4 \mathrm{ks}$ であった. Se (VI) 消失時間 も Se(VI) 50\%減少率の順とほぼ同様であったが，酒石酸だ けは例外であり $\mathrm{Se}^{0}$ の液中消失が認められた $10.8 \mathrm{ks}$ になっ ても未完了であった.

このように添加した有機酸の内特にギ酸が $\mathrm{Se}(\mathrm{VI})$ の光触 媒還元反応に効果的な理由を本研究で明確にすることは困難 であるが, $\mathrm{Se}(\mathrm{VI})$ の光触媒還元反応は $\mathrm{TiO}_{2}$ 光触媒表面上で 生起するものであるから, 前述したように $\mathrm{TiO}_{2}$ 触媒上への $\mathrm{Se}(\mathrm{VI})$ の吸着がギ酸存在下でのみ認められることが一因で あるとも考えられる.すなわち, 吸着 $\mathrm{Se}(\mathrm{VI})$ は $\mathrm{TiO}_{2}$ 触媒 上で生成した電子により効率よく還元され，正孔と電子の再 結合が少ないものと考えられる，また，ギ酸の添加が正孔に よる Se 還元生成物の再酸化の抑制に優れていることも考え られるが，本研究ではこの点の検討は行わなかった．

添加した有機酸の消費量は，反応終了時でいずれも初期濃 度の $20 \sim 27 \%$ 程度であり，UV 照射強度による有意差も認 め難い。また有機酸の消費量は $\mathrm{Se}(\mathrm{VI})$ 濃度の約 $4 \sim 5$ 倍モ ル当量に相当する.

\section{2 ギ酸の光触媒反応}

既に述べたが，十分な量のギ酸を含む $\mathrm{Se}(\mathrm{VI})$ 溶液は単に UV 照射しても供試液中に適当な光触媒が含まれていなけれ ば Se (VI) は還元されないし，ギ酸の濃度に変化は認められ ない，逆に溶液内に光触媒が含まれていても UV 照射を行 わなければやはり還元されない。また光触媒存在下で UV

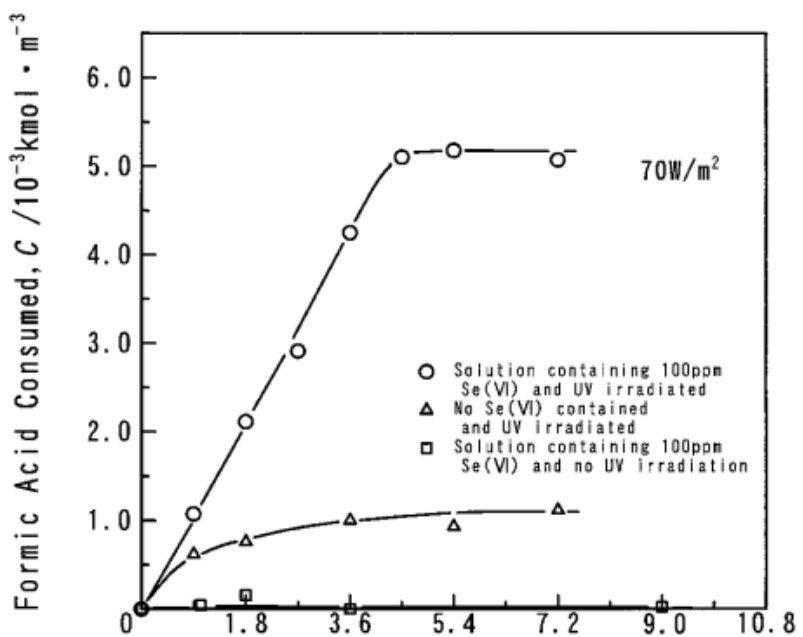

UV I rradiation Duration, $t / \mathrm{ks}$

Fig. 5 Decomposition of formic acid solution containing $\mathrm{TiO}_{2}$ catalyst in the presence and absence of Se(VI).

照射を行っても，十分な量のギ酸が存在しない溶液中では $\mathrm{Se}(\mathrm{VI})$ の還元は遅いものである.

供試液に加えた有機酸が紫外線照射によりどのような挙動 をするのかを知ることは重要である。このような見地から $\mathrm{N}_{2}$ ガスバブリング下で行った実験結果を Fig. 5 に示す。 ま ず $100 \mathrm{ppm}$ の $\mathrm{Se}(\mathrm{VI})$ と $2.5 \times 10^{-2} \mathrm{kmol} / \mathrm{m}^{3}$ のギ酸に $\mathrm{TiO}_{2}$ 触媒を加えても，これにUV 照射をしなければ全くギ酸濃 度には変化が認められない $(\square)$. ギ酸と $\mathrm{TiO}_{2}$ 粉末を含む水 溶液にUV 照射を行うとギ酸は照射時間の増大とともに分 解するが $3.6 \mathrm{ks}$ 以降は全ギ酸量の $4 \%$ 程度が分解しただけで 反応は停止する $(\triangle)$. 一方, $\mathrm{Se}(\mathrm{VI})$, ギ酸抢よび $\mathrm{TiO}_{2}$ 粉末 を含む液にUV 照射を行うと Se (VI) は還元され，それに伴 いギ酸の分解も促進され, Se (VI) 完全還元時には初期濃度 の $20 \%$ 強のギ酸が分解されたことになる $(\bigcirc)$.

ギ酸は Se $(\mathrm{VI})$ の存在により介助されて光触媒分解速度を 増すが, $\mathrm{Se}(\mathrm{VI})$ を含まない溶液内でも光触媒反応により分 解する．ただし，その反応速度ならびに反応量は Se (VI)を 含む系に比して遙かに小さい。

いずれの場合もUV 照射により生成した正孔により式 (1) 反応によりギ酸が分解されることが考えられる.

$$
\mathrm{HCOOH}+\mathrm{H}_{2} \mathrm{O}+2 \mathrm{~h}=\mathrm{H}_{2} \mathrm{CO}_{3}+2 \mathrm{H}^{+}
$$

$\mathrm{Se}(\mathrm{VI})$ から $\mathrm{Se}^{0}$ さらには $\mathrm{H}_{2} \mathrm{Se} へ$ へ分解反応は還元反応であ り，UV 照射により生じた $\mathrm{e}^{-}$を消費することを考えると $\mathrm{Se}$ (VI) 存在の条件下でギ酸の分解反応が促進されたことは容 易に理解しうる.

さらに $\mathrm{Se}(\mathrm{VI})$ の $\mathrm{H}_{2} \mathrm{Se}$ への還元反応は式 ( 2 )で示される.

$$
\mathrm{SeO}_{4}^{2-}+10 \mathrm{H}^{+}+8 \mathrm{e}^{-}=\mathrm{H}_{2} \mathrm{Se}+4 \mathrm{H}_{2} \mathrm{O}
$$

ギ酸の消費量は $\mathrm{Se}(\mathrm{VI})$ 濃度の約 4 倍モル当量に相当した が，これらの現象を総合的に考えれば，UV 照射により光触 媒 $\mathrm{TiO}_{2}$ 上で励起生成された $\mathrm{e}^{-}$を反応 $(2)$ で消費する間に 反応 $(1)$ により h を消費された結果, ギ酸の消費量は $\mathrm{Se}$ (VI) 濃度の約 4 倍モル当量になったと考えられる. しかし ながら $\mathrm{TiO}_{2}$ 光触媒上に抢ける酸化還元反応は単純ではな 
く, 式 ( 3 )で表される化学反応が進行したとは決して言え ないことは留意すべきである.

$$
\mathrm{SeO}_{4}^{2-}+4 \mathrm{HCOOH}+2 \mathrm{H}^{+}=\mathrm{H}_{2} \mathrm{Se}+4 \mathrm{H}_{2} \mathrm{CO}_{3}
$$

\section{4. 結 論}

還元性の有機酸としてギ酸, クエン酸, シュウ酸および酒 石酸を選び，それらの有機酸が，光触媒として $\mathrm{TiO}_{2}$ 粉末を 用いる $\mathrm{Se}(\mathrm{VI})$ 水溶液の紫外線照射下での還元反応に及ぼす 影響について検討し, 大略次の諸点を明らかにした。

(1) 上記 4 有機酸中, ギ酸の添加は $\mathrm{Se}(\mathrm{VI})$ 還元反応の促 進に最も有効に作用する. Se (VI) $50 \%$ 減少率到達時間はギ 酸, 酒石酸, クエン酸およびシュウ酸の順に短くなり, $\mathrm{Se}^{0}$ 最大生成率もこの順に減少する。しかし, 酒石酸は Se (VI) の完全分解を妨害し液中に Se (VI) が残存する。

(2) これらの供試有機酸自体も $\mathrm{TiO}_{2}$ 存在下で UV 照射に より分解するが, $\mathrm{Se}(\mathrm{VI})$ が含有される場合に比して遙かに 遅く且つ少量である.
（3） Se (VI)の完全還元に際して分解する有機酸の量は, 分析精度の観点から精度はそれほど高くないが，Se(VI)濃 度の約 4〜5 倍モル当量であった. 一方 $\mathrm{Se}(\mathrm{VI})$ 水溶液にこ れら有機酸を添加しただけでは Se (VI)の還元も, また有機 酸の酸化反応も全く進行しない.

（4）還元性有機酸の添加は光触媒反応時に生ずる正孔を消 費し，そのことにより $\mathrm{Se}(\mathrm{VI})$ の光触媒反応に消費される電 子の有効利用を促進すると考えられる知見を得た。

\section{文献}

1) H. Irie and K. Hashimoto: MTERE2 41(2002) 242-246.

2) S. Sanuki, T. Kojima, S. Nagaoka and H. Majima: Matall. Trans. B 30B (1999) 15-20.

3) S. Sanuki, K. Shako, S. Nagaoka and H. Majima: J. Japan Inst. Metals 64 (2000) 34-41.

4) E. Kikuchi: Shigen to Kankyo 6(2) (1997) 173-177.

5) E. Kikuchi and H. Sakamoto: J. Electrochem. Soc. 147 (2000) 4589-4593.

6) K. Rowley and E. H. Swift: Anal. Chem. 27 (1955) 818. 